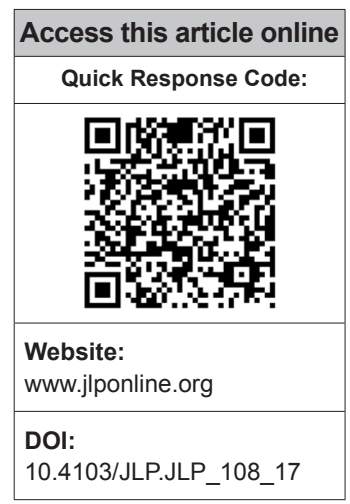

Department of Microbiology, Chettinad Hospital and Research Institute, Kanchipuram, Tamil Nadu, India

Address for correspondence:

Dr. Jayanthi Siva Subramaniyan,

Department of Microbiology, Chettinad Hospital and Research Institute, Kelambakkam, Kanchipuram - 603 103, Tamil Nadu, India. E-mail: jayanthitan@gmail.

Submission: 30-06-2017 Accepted: 28-09-2017

\section{Occurrence of bla genes encoding carbapenem-resistant Pseudomonas aeruginosa and Acinetobacter baumannii from Intensive Care Unit in a tertiary care hospital}

\author{
Jayanthi Siva Subramaniyan, Jeya Meenakshi Sundaram
}

\title{
Abstract:
}

CONTEXT: ICU shows increasing incidence of infection associated with the use of invasive procedures for the diagnostic purpose as well as the indiscriminate use of antibiotics. Pseudomonas aeruginosa and Acinetobacter species are "very successful" pathogen and the emergence of the Metallo- $\beta$-Lactamases (MBL) is becoming a therapeutic challenge.

AIMS: To isolate the Nonfermenting Gram negative bacilli from the ICU samples. To identify the metallo betalactamase producers and to detect the bla gene presence among the Pseudomonas aeruginosa and Acinetobacter baumannii.

SETTINGS AND DESIGN: The Nonfermenting Gram negative bacilli isolates from the ICU samples were taken over for 5 years (2009-2014) in a tertiary care hospital.

METHODS AND MATERIALS: The isolates of Pseudomonas species and Acinetobacter species were confirmed by API analyser and processed according to standard procedures. Detection of the MBL producers were done by E strip method and subjected for bla gene detection by PCR method.

RESULTS: In our study a total of 195 isolates of NFGNB were obtained from various ICU. Of these MBL producers, $26 \%$ were Pseudomonas aeruginosa and $25 \%$ were Acinetobacter baumannii. The subtypes of $b / a_{\mathrm{VIM}} \mathrm{MBL}$ producing P.aeruginosa were $26 \%$. The predominant gene coding for MBL activity in A.baumannii were found to be bla $a_{\mathrm{OxA}}$ gene $11.9 \%$. The gene accession numbers were KF975367, KF975372.

CONCLUSIONS: We have to control the development and dissemination of these superbugs among the ICU's.

Key words:

Acinetobacter baumanni, bla genes, ICU, Metallo- $\beta$-lactamases, Pseudomonas aeruginosa

\section{Introduction}

Tsolation of nonfermenters from the clinical Ispecimens obtained from Intensive Care Unit (ICU) shows that increasing incidence of infection associated with the use of invasive procedures, indiscriminate use of antibiotics, inadequate sterilization, and immune compromised condition due to lifestyle disease have also contributed. ${ }^{[1]}$

This is an open access article distributed under the terms of the Creative Commons Attribution-NonCommercial-ShareAlike 3.0 License, which allows others to remix, tweak, and build upon the work non-commercially, as long as the author is credited and the new creations are licensed under the identical terms.

For reprints contact: reprints@medknow.com
Among the nonfermenters, Pseudomonas aeruginosa is inherently resistant and Acinetobacter species capable of surviving in various environmental conditions are adapted at acquiring resistance. ${ }^{[2,3]}$ The digestive tracts of patients within ICUs often serve as reservoirs for multidrug-resistant (MDR) isolates. ${ }^{[4,5]}$

How to cite this article: Subramaniyan JS, Sundaram JM. Occurrence of bla genes encoding carbapenem-resistant Pseudomonas aeruginosa and Acinetobacter baumannii from Intensive Care Unit in a tertiary care hospital. J Lab Physicians 2018;10:208-13. 
$P$. aeruginosa resistance is a global disease burden ${ }^{[6]}$ and it is a therapeutic challenge. ${ }^{[7]}$ The Acinetobacter baumanii complex is emerging multidrug resistant nosocomial and community acquired pathogen. The incidence of infection by these species among the patients receiving the mechanical ventilation are quite increasing. ${ }^{[8]}$ These organisms are "very successful" pathogen which possesses both acquired and intrinsic mechanisms of resistance to various classes of antibiotics. ${ }^{[9-11]}$

Infections in the ICU patients were commonly associated with ventilator-associated pneumonia, urinary tract infection, and bacteremia caused by MDR organism Gram-negative bacilli with increasing morbidity and mortality. ${ }^{[12,13]}$ The emergence of the metallo- $\beta$-lactamases (MBL) is becoming a therapeutic challenge. ${ }^{[12]}$ Antimicrobial resistance pattern has emerged as an important determinant of the outcome for patients in the ICUs. ${ }^{[14]}$

In our study, drug-resistant isolates in the ICUs were detected and the gene encoding carbapenem resistance in P. aeruginosa and Acinetobacter baumannii was identified. The resulting sequences were compared with those available in GenBank.

\section{Methods}

All the suspected colonies of the NFGNB were identified by Gram staining, colony characteristics, oxidase test, motility, and standard biochemical reactions, and further confirmation of the species was carried out by API analyzer. The study was carried out in a tertiary care hospital (2009-2014). All the organisms identified were tested for the susceptibility according to the standard Clinical and Laboratory Standards Institute guidelines. ${ }^{[15]}$ The sensitivity pattern of first- and second-line drugs was tested.

For Pseudomonas species, the following 15 drugs were used: amikacin (Ak-30 $\mu \mathrm{g})$, aztreonam (Az-30 $\mu \mathrm{g})$, colistin $(\mathrm{Cl}-10 \mu \mathrm{g})$, ciprofloxacin (Cip-5 $\mu \mathrm{g})$, ceftazidime (Caz-5 $\mu \mathrm{g})$, cefepime (Cpm-5 $\mu \mathrm{g})$, carbenicillin $(\mathrm{Cb}-100 \mu \mathrm{g})$, gentamicin (G-10 $\mu \mathrm{g})$, imipenem (Imp-10 $\mu \mathrm{g})$, meropenem $(\mathrm{Mr}-10 \mu \mathrm{g})$, netilmicin (Net-30 $\mu \mathrm{g})$, ofloxacin (Of-5 $\mu \mathrm{g}$ ), piperacillin-tazobactam (Pit-100 $\mu \mathrm{g} / 10 \mu \mathrm{g}$ ), polymyxin B (Pb-300 units), tobramycin ( $\mathrm{Tb}-10 \mu \mathrm{g})$.

For Acinetobacter species, amikacin (Ak-30 $\mu \mathrm{g})$, cefepime $(\mathrm{Cpm}-5 \mu \mathrm{g})$, ceftazidime (Caz-5 $\mu \mathrm{g})$, ciprofloxacin (Cf-5 $\mu \mathrm{g})$, cefotaxime (Ce-5 $\mu \mathrm{g})$, colistin (E strip), cotrimoxazole (Cot-5 $\mu \mathrm{g})$, gentamicin (G-10 $\mu \mathrm{g})$, imipenem (IMP-10 $\mu \mathrm{g}$ ), meropenem (Mr-10 $\mu \mathrm{g}$ ), piperacillin-tazobactam $(\mathrm{Pt}-100 \mu \mathrm{g} / 10 \mu \mathrm{g})$, and polymyxin B (E strip) were used, and in case of urine samples, nitrofurantoin (Nit-300 $\mu \mathrm{g}$ ) disks were used.
The study was confined to the MBL-producing $P$. aeruginosa and $A$. baumannii species. The antibiotic discs used in our study were purchased from HiMedia. The E strip was purchased from HiMedia, Biomerieux, and Radianz biotechnologies. Screening for MBL production was done in imipenem-resistant isolates by the E strip method using the ceftazidime and ceftazidime + ethylenediaminetetraacetic acid. ${ }^{[16]}$

The MBL-producing resistant strains of $P$. aeruginosa were screened for the bla genes $-b l a_{\mathrm{VIM}, \mathrm{KPC}, \mathrm{NDM}, \mathrm{IMP}}{ }^{[1,17-21]}$ [Table 1]. For A. baumannii, bla ${ }_{\mathrm{VIM}}$, IMP, OXA, NDM genes [Table 2] were carried out. ${ }^{[1,18,21-23]}$

\section{Polymerase chain reaction amplification}

The reaction conditions were as follows: predenaturation

Table 1: The primers used for bla gene detection in Pseudomonas aeruginosa

\begin{tabular}{|c|c|c|c|}
\hline Gene & Primers & & $\begin{array}{l}\text { Product } \\
\text { size }\end{array}$ \\
\hline bla $_{\text {VIM A }}$ & $\begin{array}{l}\text { Forward } \\
\text { primer }\end{array}$ & 5'TCT ACA TGA CCG CGT CTG TC-3' & $748 \mathrm{bp}$ \\
\hline bla $_{\text {VIM B }}$ & $\begin{array}{l}\text { Reverse } \\
\text { primer }\end{array}$ & 5'TGT GCT TTG ACA ACG TTC GC-3' & \\
\hline bla $_{\mathrm{IMP}}$ & $\begin{array}{l}\text { Forward } \\
\text { primer }\end{array}$ & $\begin{array}{l}\text { 5' CCA GAT TTA AAA ATA GAG AAG } \\
\text { CTT G-3' }\end{array}$ & $587 \mathrm{bp}$ \\
\hline bla $_{\text {IMP }}$ & $\begin{array}{l}\text { Reverse } \\
\text { primer }\end{array}$ & $\begin{array}{l}\text { 5' TGG CCA AGC TTC TAC ATT TGC } \\
\text { GTC -3' }\end{array}$ & \\
\hline bla $_{\mathrm{NDM}}$ & $\begin{array}{l}\text { Forward } \\
\text { primer }\end{array}$ & $\begin{array}{l}\text { 5' GGT TTT GGC GAT CTG GTT TTC } \\
\text { 3' }\end{array}$ & $522 \mathrm{bp}$ \\
\hline bla $_{\text {NDM }}$ & $\begin{array}{l}\text { Reverse } \\
\text { primer }\end{array}$ & 5' CGG AAT GGC TCA TCA CGA TC 3' & \\
\hline $\mathrm{bla}_{\mathrm{KPC}}$ & $\begin{array}{l}\text { Forward } \\
\text { primer }\end{array}$ & $\begin{array}{l}\text { 5' GCT ACA CCT AGC TCC ACC } \\
\text { TTC-3' }\end{array}$ & $989 b p$ \\
\hline $\mathrm{bla}_{\mathrm{KPC}}$ & $\begin{array}{l}\text { Reverse } \\
\text { primer }\end{array}$ & $\begin{array}{l}\text { 5' ACA GTG GTT GGT AAT CCA } \\
\text { TGC-3' }\end{array}$ & \\
\hline
\end{tabular}

Table 2: The primers used for bla gene detection in Acinetobacter baumannii

\begin{tabular}{|c|c|c|}
\hline Gene & Primers & $\begin{array}{l}\text { Product } \\
\text { size }\end{array}$ \\
\hline bla $_{\mathrm{VIM}}$ & $\begin{array}{l}\text { Forward -5'-GTGCTTTGACAACGTTCGCT-3' } \\
\text { primer }\end{array}$ & $442 b p$ \\
\hline bla $_{\text {vIM }}$ & $\begin{array}{l}\text { Reverse -5'-TCCACGCACTTTCATGACGA-3' } \\
\text { primer }\end{array}$ & \\
\hline bla $_{\text {IMP }}$ & $\begin{array}{l}\text { Forward - 5' -TTTTGCAGCATTGCTACCGC-3' } \\
\text { primer }\end{array}$ & $220 \mathrm{bp}$ \\
\hline bla $_{\text {IMP }}$ & $\begin{array}{l}\text { Reverse - 5' -CACGCTCCACAAACCAAGTG-3' } \\
\text { primer }\end{array}$ & \\
\hline $\mathrm{bla}_{\mathrm{OXA}}$ & $\begin{array}{l}\text { Forward -5'-AGTATTGGGGCTTGTGCT-3' } \\
\text { primer }\end{array}$ & 398bp \\
\hline bla $_{\mathrm{OXA}}$ & $\begin{array}{l}\text { Reverse -5'-AACTTCCGTGCCTATTTG-3' } \\
\text { primer }\end{array}$ & \\
\hline bla $_{\mathrm{NDM}}$ & $\begin{array}{l}\text { Forward 5' GGT GCA TGC CCG GTG AAA TC 3' } \\
\text { primer }\end{array}$ & $660 \mathrm{bp}$ \\
\hline \multirow[t]{2}{*}{ bla $_{\mathrm{NDM}}$} & $\begin{array}{l}\text { Reverse 5' ATG CTG GCC TTG GGG AAC G 3' } \\
\text { primer }\end{array}$ & \\
\hline & Internal control & $400 \mathrm{bp}$ \\
\hline
\end{tabular}


at $94^{\circ} \mathrm{C}$ for $2 \mathrm{~min}$, followed by 30 amplifications cycles of $94^{\circ} \mathrm{C}$ for $1 \mathrm{~min}, 55^{\circ} \mathrm{C}$ for $1 \mathrm{~min}$, and $72^{\circ} \mathrm{C}$ for $1 \mathrm{~min}$ $30 \mathrm{sec}$, with final extension step of $72^{\circ} \mathrm{C}$ for $5 \mathrm{~min}$. The cycling parameters for the $b a_{\mathrm{IMP}, \mathrm{VIM}}, \mathrm{NDM}$, oxA genes were as follows: initial denaturation: $94^{\circ} \mathrm{C}$ for $3 \mathrm{~min}$, denaturation: $94^{\circ} \mathrm{C}$ for $1 \mathrm{~min}$, annealing: $58^{\circ} \mathrm{C}$ for $1 \mathrm{~min}$ 35 cycles, extension: $72^{\circ} \mathrm{C}$ for $1 \mathrm{~min}$, final extension: $72^{\circ} \mathrm{C}$ for $5 \mathrm{~min}$. After screening for the MBL, the positive PCR products were sequenced. Sequencing the amplified products, the BLAST results were analyzed.

\section{Results}

The nonfermenters isolated from ICU were found to be notorious as there were possibilities of drug-resistant strains being horizontally spread among the patients. In our study, a total of 195 isolates of NFGNB were obtained from various ICUs. Among them, 61 (31.2\%) were Pseudomonas spp and 134 (68.8) were Acinetobacter spp. Among the 84 isolates of NFGNB, $32(38 \%)$ were $P$. aeruginosa and $61.9 \% A$. baumannii were isolated from surgical ICU. Distribution of NFGNB - P. aeruginosa and A. baumannii in different ICUs is shown in Table 3. Among $61 P$. aeruginosa from ICU patients, 19 (31.1\%) were from males and $42(68.8 \%)$ were from females. Distribution of $P$. aeuginosa from ICU among different sexes is shown in Chart 1 . Among 134 A. baumannii from ICU patients, 89 (66.4\%) were from males and $45(33.5 \%)$ were from females [Chart 2].

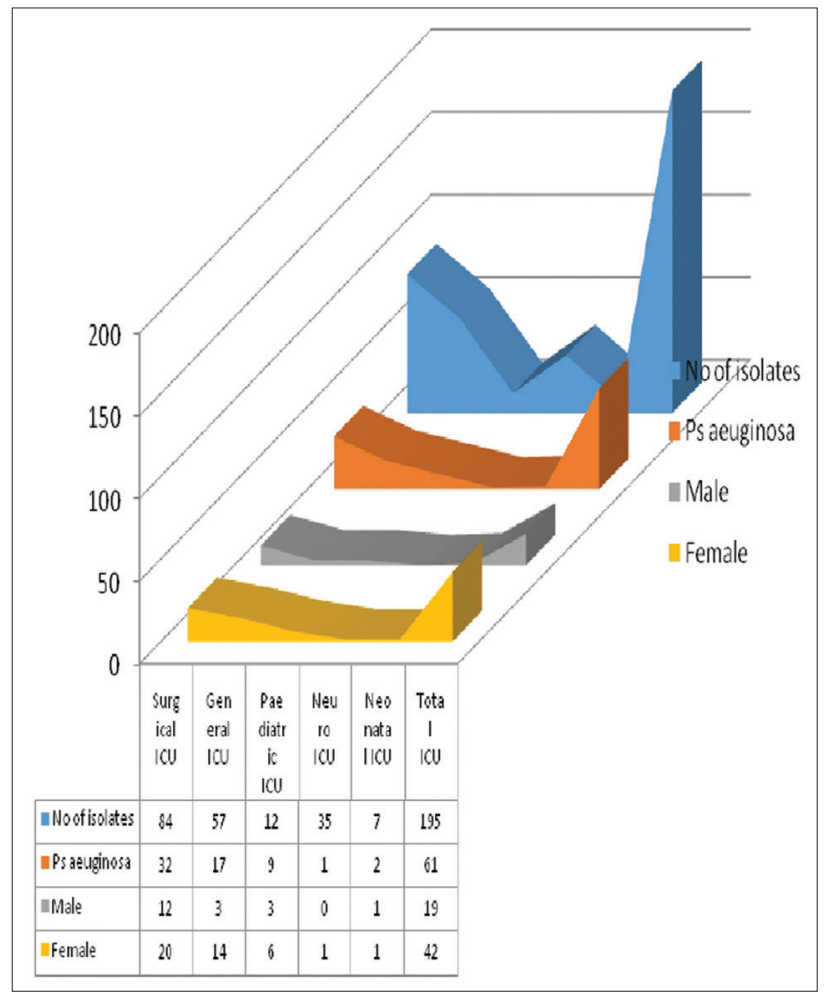

Chart 1: Distribution of Pseudomonas aeruginosa from Intensive Care Unit among different sexes
Among 195 NFGNB isolates from ICU, 89 (45.6\%) were drug resistant. Out of these, $26(13.33 \%)$ were $P$. aeruginosa and $63(32.3 \%)$ were $A$. baumannii. Overall, the MDR isolates from ICU were $33.33 \%$. The MBL producers from ICU were $49(25.12 \%)$ [Table 4]. Of these MBL producers, $16(26.22 \%)$ were $P$. aeruginosa and $33(24.62 \%)$ were A. baumannii [Table 5 and Chart 3 ].

The maximum numbers of MBL producers were in surgical ICU followed by general ICU. Among ICUs, $6.1 \%$ of isolates were from pediatric ICU and one isolate of $P$. aeruginosa was MBL producer [Table 6]. Among the MBL producers in ICU, P. aeruginosa was obtained from

Table 3: Distribution of P.aeruginosa and A.baumannii in different ICUs

\begin{tabular}{lccc}
\hline Source & $\begin{array}{c}\text { No of } \\
\text { isolates }\end{array}$ & P.aeuginosa (\%) & A.bauamannii (\%) \\
\hline Surgical ICU & 84 & $32(38)$ & $52(61.9)$ \\
General ICU & 57 & $17(29.8)$ & $40(70.1)$ \\
Paediatric ICU & 12 & $9(75)$ & $3(25)$ \\
Neuro ICU & 35 & $1(2.8)$ & $34(97.2)$ \\
Neonatal ICU & 7 & $2(28.5)$ & $5(71.4)$ \\
Total ICU & 195 & 61 & 134 \\
\hline
\end{tabular}

Table 4: Drug resistance in ICU isolates

\begin{tabular}{lccc}
\hline $\begin{array}{l}\text { Isolates from } \\
\text { ICU }(n)\end{array}$ & $\begin{array}{c}\text { Drug resistant } \\
\text { isolates }\end{array}$ & $\begin{array}{c}\text { Multidrug } \\
\text { resistant } \\
\text { isolates }\end{array}$ & $\begin{array}{c}\text { Metallo beta } \\
\text { lactamase } \\
\text { producers }\end{array}$ \\
\hline P.aeruginosa (61) & 26 & 23 & 16 \\
A.baumannii (134) & 63 & 42 & 33 \\
Total (195) & 89 & 65 & 49 \\
\hline
\end{tabular}

Table 5: Showing MBL positive by Estrip method

\begin{tabular}{lcc}
\hline Method (E strip-MIC E strip) & $\begin{array}{c}P \text {. aeruginosa } \\
(n=26)\end{array}$ & $\begin{array}{c}\text { A. baumanii } \\
(n=63)\end{array}$ \\
\hline CDT - Imp, Imp + EDTA & 16 & 33 \\
\hline
\end{tabular}

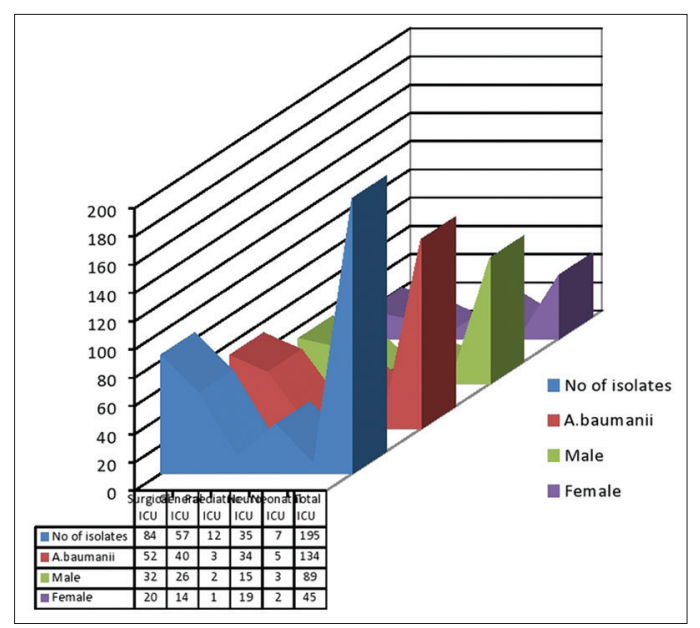

Chart 2: Distribution of Acinetobacter baumannii from Intensive Care Unit among different sexes 
11 males and 5 females and A. baumannii was isolated from 13 males and 20 females.

MDR and MBL producers were more from general ICU and surgical ICU. Among the 63 drug-resistant A. baumannii, $42(66.6 \%)$ were multidrug resistant and 33 (52.3\%) were MBL producer.

Clinical sources of the MBL-producing P. aeruginosa are shown in Table 7. The subtypes of $b a_{\text {VIM }}$ MBL-producing $P$. aeruginosa were $26 \%$ and strains of $P$. aeruginosa

Table 6: Distribution in Paediatric ICU

\begin{tabular}{lccc}
\hline Organisms & $\begin{array}{c}\text { No of } \\
\text { isolates }\end{array}$ & $\begin{array}{c}\text { No of MDR } \\
\text { isolates }\end{array}$ & $\begin{array}{c}\text { No of MBL } \\
\text { isolates }\end{array}$ \\
\hline P.aeruginosa $(n=61)$ & 9 & 2 & 1 \\
A.baumannii $(n=134)$ & 3 & 1 & 0 \\
Total $(n=195)$ & $12(6.1 \%)$ & $3(1.5 \%)$ & $1(0.5 \%)$ \\
\hline
\end{tabular}

Table 7: Clinical source of P.aeruginosa with $b / a_{\mathrm{VIM}}$ gene subtypes

\begin{tabular}{lccc}
\hline Sample source & $\boldsymbol{b l a}_{\text {VIM38 }}$ & $\boldsymbol{b l a}_{\text {VIM5 }}$ & $\boldsymbol{b l a}_{\mathrm{VIM} 4}$ \\
\hline Tracheal aspirate & - & 1 & 3 \\
Wound swab & - & 2 & 2 \\
CVP tip & 2 & 1 & - \\
Pleural fluid & - & 1 & - \\
Pus & - & 1 & 1 \\
Blood & - & - & 2 \\
\hline
\end{tabular}

Table 8: Clinical source of A.baumannii with bla gene subtypes

\begin{tabular}{lccc}
\hline Sample source & $\boldsymbol{b l a}_{\text {oXA }}$ & $\boldsymbol{b l a}_{\text {VIM }}$ & $b / a_{\text {IMP }}$ \\
\hline Tracheal aspirate & 2 & - & - \\
Wound swab & - & 4 & 3 \\
CVP tip & 4 & - & - \\
Pleural fluid & 2 & - & - \\
Pus & 8 & - & 4 \\
Blood & - & 2 & - \\
\hline
\end{tabular}

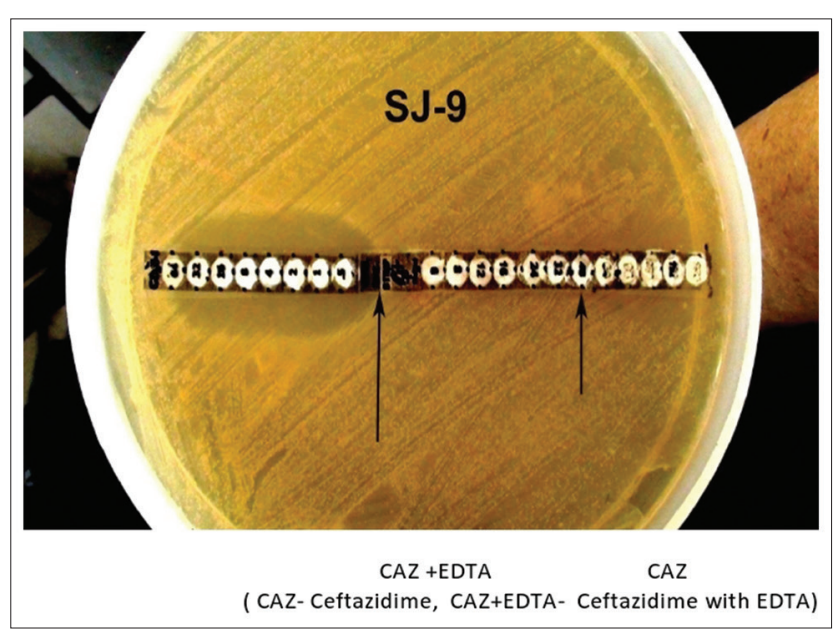

Chart 3: MIC E strip from ICU were negative for other $b l a_{\mathrm{KPC}, \mathrm{NDM}}$, IMP genes. Distribution of all three subtypes of MBL-producing P. aeruginosa was as follows: $13.1 \%$ bla $a_{\mathrm{VIM}-4^{\prime}} 9.8 \% b l a_{\mathrm{VIM}-5^{\prime}}$ and $3.2 \%$ bla $_{\mathrm{VIM}-38}$ strains [Chart 4$]$.

In MBL-positive A. baumannii, bla $a_{\mathrm{VIM}}$ genewas demonstrated in $4.4 \%$ strains, $b l a_{\mathrm{OXA}}$ gene was seen in $11.9 \%$, and $b l a_{\mathrm{IMP}}$ gene was seen in $5.2 \%$. Thus, the predominant gene coding for MBL activity was found to be OXA. Distribution of genes responsible for MBL activity in A. baumannii and its clinical source is shown in Table 8 . The resulting sequences were compared with those available in GenBank (www.ncbi.nih.gov/BLAST) and the gene accession numbers were KF975367, KF975372.

\section{Discussion}

There is an increase in infection caused by the MBL-producing NFGNB in the ICUs, along with the significant morbidity and mortality. The incidence of infection in ICUs, especially the nosocomial infections, is a rising trend with a spectrum of clinical conditions. They may be in the range from impaired immunity, lapse in the sterilization, use of various invasive devices, and procedure to indiscriminate use of antibiotics.

A study by Aliskan et al. ${ }^{[24]}$ showed that there was a decrease in susceptibility pattern of $A$. baumannii and $P$. aeruginosa isolates from the ICU samples. In our study, maximum $P$. aeruginosa and $A$. baumannii were from tracheal aspirates, followed by wound swab which was in concordance with study of Jaggi et al. ${ }^{[25]}$

In a study by Orrett, $17.3 \%$ of $P$. aeruginosa were from ICU. ${ }^{[26]}$ The prevalence of Acinetobacter species from various parts of our country was 3\%, ${ }^{[27]} 4.5 \%,{ }^{[28]} 9.6 \%$ in West Bengal. ${ }^{[29]}$ In our study, the prevalence of P. aeruginosa (31.2\%) and A. baumannii (68.8\%) in ICU was higher when compared with above study. Among the

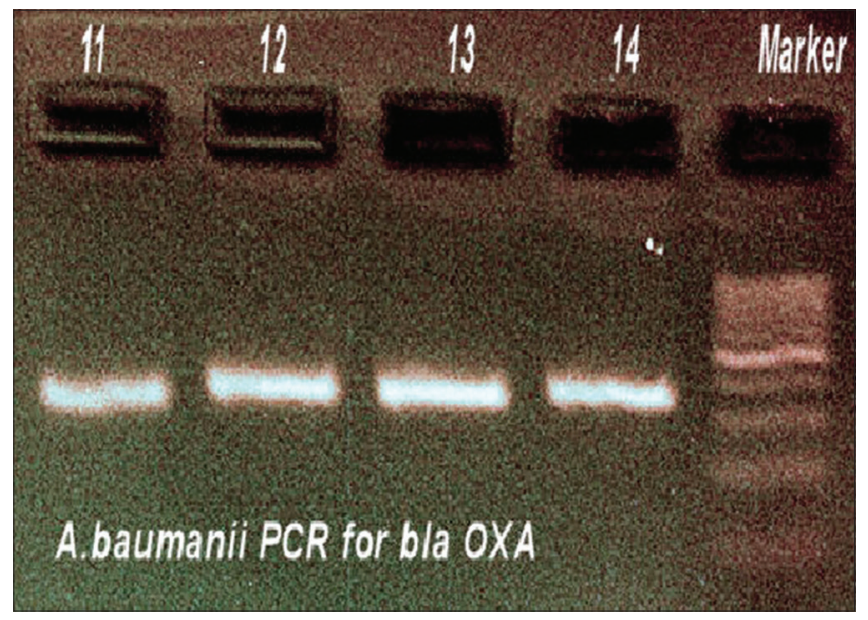

Chart 4: Polymerase chain reaction for Acinetobacter baumannii bla ${ }_{\mathrm{OXA}}$ 
A. baumannii strains isolated from ICU, $65 \%-70 \%$ were resistant and they were not in concordance with our study ${ }^{[3,30,31]}$ which is higher when compared to our study.

The percentage of MDR A. baumannii isolates increased from $4 \%$ to $55 \%$ and $2 \%-8 \%$ in P. aeruginosa isolates. According to Yan et al., $56.7 \%$ and $58.3 \%$ of P. aeruginosa were found to be imipenem resistant. ${ }^{[3,32]}$

Many studies have reported $<50 \%$ of resistance to imipenem and meropenem in P. aeruginosa. Imipenem resistance according to Livermore ${ }^{[33]}$ was $77.5 \%$ and Lone et al. ${ }^{[34]}$ was $25.6 \%$. Tan ${ }^{[35]}$ reported that $9.6 \%$ carbapenem-resistant $P$. aerugionsa and $27.2 \%$ carbapenem-resistant $P$. aerugionsa were from ICU reported by Hsu et al. ${ }^{\left[{ }^{[6]}\right.}$ In our study, carbapenem-resistant Acinetobacter spp. isolated from ICU were $25 \%$ and lesser than the resistance pattern (69\%) reported by Tan. ${ }^{[35]}$

A study by Hsu et al. ${ }^{[36]}$ showed that carbapenem resistance of Acinetobacter was $49.6 \%$. Lagatolla et al..$^{[37]}$ showed that $70 \%$ of carbapenem-resistant $P$. aeruginosa were MBL producers. A study by Kabbaj et al. ${ }^{[38]}$ showed that, among $57.4 \%$ imipenem-resistant isolates of Acinetobacter bauamnii, $74 \%$ were MBL producers and in concordance with our study. An Indian study stated that MBL producers among the A. baumannii were $70.9 \%$, ${ }^{[39]}$ and another study reported that $21 \%{ }^{[40]}$ of $A$. baumannii were MBL producers.

Tanzinah Nasrin showed the high level of MBL producers isolated from ICU unlike our study. Studies from the Indian subcontinent have shown the $b l a_{\mathrm{IMP1}}$ gene carried by meropenem-resistant isolates. ${ }^{[41]}$ Our study confirmed the presence of $b l a$ gene $\left(b l a_{\mathrm{VIM}} 26 \%\right.$ and $\left.b l a_{\mathrm{OXA}} 12 \%\right)$ among the isolates of $P$. aeruginosa and $A$. baumannii from the ICU samples and comparable with the study of Gautam et al., ${ }^{[30]}$ $25 \%$ prevalence of NDM-1 A. baumannii in ICU isolates.

\section{Conclusion}

We have to control the development and dissemination of these superbugs among the ICUs. Insight into the incidence of these superbugs alarms the need of every institution to have the interventional strategies to prevent these infections. The prevalence in ICU emphasizes the need for early detection of beta-lactamases-producing organisms.

\section{Acknowledgement}

My sincere gratitude goes to Dr.Sundararaj.T, (Ret) Prof and Head of Dept of Microbiology, Dr.A.L.Mudaliar Post- Graduate Institute of Basic Medical Sciences. Tharamani, Chennai \& Director of JASMN Education and Foundation, JASMN Laboratory, who has guided and spent valuable time during the course of our work.

\section{Financial support and sponsorship} Nil.

\section{Conflicts of interest}

There are no conflicts of interest.

\section{References}

1. Murray PR, Rosenthal KS, Pfaller MA, editors. Text Book of Medical Microbiology-Pseudomonas and Related Organisms. $5^{\text {th }}$ ed. Vol. 34. Elsevier; 2005. p. 357-65.

2. Towner KJ. Plasmid and transposon behaviour in Acinetobacter. In: Towner KJ, Bergogne-Berezin E, Fewson CA, editors. The Biology, Physiology, Industrial Relevance. New York: Plenum Press; 1991. p. 149-67.

3. Cisneros JM, Rodríguez-Baño J, Fernández-Cuenca F, Ribera A, Vila J, Pascual A, et al. Risk-factors for the acquisition of imipenem -Resistant Acinetobacter baumannii in Spain: A nationwide study. Clin Microbiol Infect 2005;11:874-9.

4. Corbella X,Pujol M, Ayats J,Sendra M, Ardanuy C, Domínguez MA, et al. Relevance of digestive tract colonization in the epidemiology of nosocomial infections due to multiresistant Acinetobacter baumannii. Clin Infect Dis 1996;23:329-34.

5. Afzal-Shah M, Livermore DM. Worldwide emergence of carbapenem-resistant Acinetobacter spp. J Antimicrob Chemother 1998;41:576-7.

6. Paramythiotou E, Lucet JC, Timsit JF. Acquistion of multidrug resistant Pseudomonas aeruginosa in patients in Intensive Care Units: Role of antibiotics with antipseudomonal activity. Clin Infect Dis 2003;38:676-7.

7. Lister PD, Wolter DJ, Hanson ND. Antibacterial-resistant Pseudomonas aeruginosa: Clinical impact and complex regulation of chromosomally encoded resistance mechanisms. Clin Microbiol Rev 2009;22:582-610.

8. Talbot GH, Bradley J, Edwards JE Jr., Gilbert D, Scheld M, Bartlett JG, et al. Bad Bugs need drugs: An update on the development pipeline from the antimicrobial availability task force of the infectious diseases society of America. Clin Infect Dis 2006;42:657-68.

9. Perez F, Hujer AM, Hujer KM, Decker BK, Rather PN, Bonomo RA, et al. Global challenge of multidrug-resistant Acinetobacter baumannii. Antimicrob Agents Chemother 2007;51:3471-84.

10. Rice LB. Challenges in identifying new antimicrobial agents effective for treating infections with Acinetobacter baumannii and Pseudomonas aeruginosa. Clin Infect Dis 2006;43 Suppl 2:S100-5.

11. Garnacho-Montero J, Amaya-Villar R. Multi resistant Acinetobacter baumannii infections: Epidemiology and management. Curr Opin Infect Dis 2010;23:332-9.

12. Irfan S, Zafar A, Guhar D, Ahsan T, Hasan R. Metallo-beta-lactamase-producing clinical isolates of Acinetobacter species and Pseudomonas aeruginosa from intensive care unit patients of a tertiary care hospital. Indian J Med Microbiol 2008;26:243-5.

13. Oberoi L, Singh N, Sharma P, Aggarwal A. ESBL, MBL and ampc $\beta$ lactamases producing superbugs - Havoc in the intensive care units of Punjab India. J Clin Diagn Res 2013;7:70-3.

14. Mohanasundaram KM. Retrospective analysis of the incidence of nosocomial infection in the ICU-associated risk factors and microbiological profile. J Clin Diagn Res 2010;4:33789-2.

15. Clinical and Laboratory Standards Institute. Performance Standards for the Antimicrobial Susceptibility Testing. CLSI Document M100-S20. Wayne, PA, USA: Clinical and Laboratory Standards Institute; 2010.

16. Segal H, Elisha BG. Use of E test MBL strips for the detection of carbapenemases in Acinetobacter baumannii. J Antimicrob 
Chemother 2005;56:598.

17. Giakkoupi P, Xanthaki A, Kanelopoulou M, Vlahaki A, Miriagou V, Kontou S, et al. VIM-1 metallo-beta-lactamase-producing Klebsiella pneumoniae strains in Greek hospitals. J Clin Microbiol 2003;41:3893-6.

18. Dong F, XuXW,SongWQ,LüP, YuSJ, Yang YH,etal.Characterization of multidrug-resistant and metallo-beta-lactamase-producing Pseudomonas aeruginosa isolates from a paediatric clinic in China. Chin Med J (Engl) 2008;121:1611-6.

19. Gutiérrez O, Juan C, Cercenado E, Navarro F, Bouza E, Coll P, et al. Molecular epidemiology and mechanisms of carbapenem resistance in Pseudomonas aeruginosa isolates from Spanish hospitals. Antimicrob Agents Chemother 2007;51:4329-35.

20. Juan C, Beceiro A, Gutiérrez O, Albertí S, Garau M, Pérez JL, et al. Characterization of the new metallo-beta-lactamase VIM-13 and its integron-borne gene from a Pseudomonas aeruginosa clinical isolate in Spain. Antimicrob Agents Chemother 2008;52:3589-96.

21. Lauretti L, Riccio ML, Mazzariol A, Cornaglia G, Amicosante G, Fontana $R$, et al. Cloning and characterization of bla VIM, a new integron-borne metallo-beta-lactamase gene from a Pseudomonas aeruginosa clinical isolate. Antimicrob Agents Chemother 1999;43:1584-90.

22. Yum JH, Yi K, Lee H, Yong D, Lee K, Kim JM, et al. Molecular characterization of metallo-beta-lactamase-producing Acinetobacter baumannii and Acinetobacter genomospecies 3 from Korea: Identification of two new integrons carrying the bla (VIM-2) gene cassettes. J Antimicrob Chemother 2002;49:837-40.

23. Sundararaj T, Sundararaj A. Microbiology Laboratory Manual. $4^{\text {th }}$ ed. Vol. 1. A.Sundararaj; 2005. p. 39-40.

24. Alişkan H, Colakoğlu S, Turunç T, Demiroğlu YZ, Erdoğan F, Akin $S$, et al. Four years of monitoring of antibiotic sensitivity rates of Pseudomonas aeruginosa and Acinetobacter baumannii strains isolated from patients in Intensive Care Unit and inpatient clinics. Mikrobiyol Bul 2008;42:321-9.

25. Jaggi N, Sissodia P, Sharma L. Acinetobacter baumannii isolates: The epidemiology, antibiogram and the nosocomial status which were studied over a 25 months period in a tertiary care hospital in India. BMC Proc 2011;5:291.

26. Orrett FA. Antimicrobial susceptibility survey of Pseudomonas aeruginosa strains isolated from clinical sources. J Natl Med Assoc 2004;96:1065-9.

27. Dash M, Padhi S, Pattnaik S, Mohanty I, Misra P. Frequency, risk factors, and antibiogram of Acinetobacter species isolated from various clinical samples in a tertiary care hospital in Odisha, India. Avicenna J Med 2013;3:97-102.

28. Rit K, Saha R. Multidrug-resistant Acinetobacter infection and their susceptibility patterns in a tertiary care hospital. Niger Med J 2012;53:126-8.
29. Joshi SG, Litake GM, Satpute MG, Telang NV, Ghole VS, Niphadkar KB, et al. Clinical and demographic features of infection caused by Acinetobacter species. Indian J Med Sci 2006;60:351-60.

30. Gautam V, Mewara A, Raj A, Gupta V, Singla N, Ray P, et al. High prevalence of New Delhi metallo- $\beta$-lactamase in Acinetobacter calcoaceticus-A. Baumannii complex at two tertiary care centres in North India. Indian J Med Microbiol 2014;32:455-6.

31. Abbo A, Navon-Venezia S, Hammer-Muntz O, Krichali T, Siegman-Igra Y, Carmeli Y, et al. Multidrug-resistant Acinetobacter baumannii. Emerg Infect Dis 2005;11:22-9.

32. Yan JJ, Ko WC, Tsai SH, Wu HM, Wu JJ. Outbreak of infection with multidrug resistant Klebsiella pneumonia carrying bla IMP -8 in a university medical centre in Taiwan. J Clin Microbiol 2001;39:4433-9.

33. Livermore DM. Multiple mechanisms of antimicrobial resistance in Pseudomonas aeruginosa: Our worst nightmare? Clin Infect Dis 2002;34:634-40.

34. Lone R, Shah A, Kadri SM, Lone S, Shah F. Nosocomial multidrug resistant Acinetobacter infections-clinical findings, risk factors and demographic characteristics. Bangladesh J Med Microbiol 2009;3:34-8.

35. Tan TT. "Future" threat of Gram negative resistance in Singapore. Ann Acad Med Singapore 2008;37:884-90.

36. Hsu LY, Tan TY, Jureen R, Koh TH, Krishnan P, Tzer-Pin Lin R, et al. Antimicrobial drug resistance in Singapore hospitals. Emerg Infect Dis 2007;13:1944-7.

37. Lagatolla C, Tonin EA, Monti-Bragadin C, Dolzani L, Gombac F, Bearzi C, et al. Endemic carbapenem-resistant Pseudomonas aeruginosa with acquired metallo-beta-lactamase determinants in European hospital. Emerg Infect Dis 2004;10:535-8.

38. Kabbaj H, Seffar M, Belefquih B, Akka D, Handor N, Amor M, et al. Prevalence of Metallo betalactamases producing Acinetobacter baumannii in a Moroccan hospital. ISRN Infect Dis 2013;2013:154921.

39. Uma Karthika R, Srinivasa Rao R, Sahoo S, Shashikala P, Kanungo R, Jayachandran S, et al. Phenotypic and genotypic assays for detecting the prevalence of metallo-beta-lactamases in clinical isolates of Acinetobacter baumannii from a South Indian tertiary care hospital. J Med Microbiol 2009;58:430-5.

40. Anil VK, Vishnu SP, Kavitha R, Shamusul D. The phenotypic detection of carbapenemase in the meropenem resistant Acinetobacter calcoaceticus-baumannii complex in a tertiary care hospital in S. I. J Clin Diagn Res 2011;5:223-6.

41. Azim A, Dwivedi M, Rao PB, Baronia AK, Singh RK, Prasad KN, et al. Epidemiology of bacterial colonization at Intensive Care Unit admission with emphasis on extended-spectrum beta-lactamase-and metallo-beta-lactamase-producing Gram-negative bacteria - An Indian experience. J Med Microbiol 2010;59:955-60. 